\title{
PERBANDINGAN PERLAKUAN T6 DAN TEMPERING CASE HARDENING ALUMINIUM 7075 TERHADAP SIFAT MEKANIK
}

\author{
Febri Budi Darsono ${ }^{1}$, Sudibtia Titio Koin ${ }^{2}$, Akhmad Nurdin ${ }^{3}$ \\ ${ }^{1}$ Jurusan Teknik Mesin, Fakultas Teknik, Universitas Negeri Semarang. \\ ${ }^{2}$ Program Studi Teknik Mesin Industri, Politeknik ATMI Surakarta. \\ ${ }^{3}$ Program Studi Teknologi Pengecoran Logam, Politeknik Manufaktur Ceper. \\ ${ }^{1}$ Febribudi@mail.unnes.ac.id \\ 2tio.atmi@gmail.com \\ 33akhmadnurdin.89@gmail.com
}

\begin{abstract}
ABSTRAK
Aluminium merupakan logam yang paling banyak digunakan setelah baja, dengan karakteristik utamanya adalah ringan (berat jenis $=2.7 \mathrm{~g} / \mathrm{cm}^{3}$ ), memiliki konduktivitas panas dan listrik yang tinggi, dan ketahanan korosi yang baik. Penggunaan aluminium menempati urutan kedua setelah besi dan baja dan digunakan sebagai bahan untuk komponen industri otomotif, salah satu penggunaanya yaitu berupa komponen pada mobil. Aluminium yang digunakan seri 7075 yang mana memiliki sifat paling baik dan kekuatan paling tinggi dibandingkan paduan aluminium lainnya. Aluminium seri 7075 merupakan seri yang dapat diberikan perlakuan panas, perlakuan panas yang digunakan yaitu tempering dan case hardening, yang mana perlakuan tersebut dapat meningkatkan sifat mekanik aluminium 7075. Metode perlakuan panas yang digunakan yaitu proses tempering case hardening $(\mathrm{TCH})$ dan $\mathrm{T} 6$, dengan variasi suhu solution heat treatment (SHT) $350^{\circ} \mathrm{C}, 400^{\circ} \mathrm{C}, 450^{\circ} \mathrm{C}$ dan $500^{\circ} \mathrm{C}$. Proses tempering T6 tahapannya: a). Pemanasan suhu SHT dengan variasi suhu $\left(350-500^{\circ} \mathrm{C}\right)$, b). Quenching, dan c). Tempering (dengan suhu $120^{\circ} \mathrm{C}$ selama 2 hari). Sedangkan proses tempering case hardening, proses temper dilakukan setelah proses case hardening dengan metode pack carburizing. Pengujian yang dilakukan yaitu: uji kekerasan vickers, uji tarik, uji struktur mikro dan uji xrd, hasil menunjukkan setelah perlakuan TCH dan T6 didapatkan kekerasan dan kekuatan tarik terbesar pada suhu SHT $500{ }^{\circ} \mathrm{C}$ yaitu kekerasannya 182.5 dan 171 VHN, kekuatan tariknya 613.3 dan 618.3 MPa.
\end{abstract}

Kata kunci: Aluminium 7075, Tempering Case Hardening, T6, Kekerasan Vickers, Kekuatan Tarik.

\section{ABSTRACT}

Comparison of T6 and Tempering Case Hardening Aluminum 7075 Treatment on Mechanical Properties. Aluminum is the most commonly used metal after steel, with its main characteristics being light weight $\left(\right.$ density $\left.=2.7 \mathrm{~g} / \mathrm{cm}^{3}\right)$, high thermal and electrical conductivity, and good corrosion resistance. Aluminum is used as a part material in the automotive industry on second ranks, and one of its applications is in the form of car parts. The aluminum used in the 7075 series has the best properties and the highest strength compared to other aluminum alloys. Aluminum 7075 is a heat-treatable, tempering and case hardening are two heat treatments that can increase the mechanical properties of aluminum 7075. The heat treatment methods used are the temper case hardening (TCH) and T6 tempering processes, with variations temperature of solution heat treatment (SHT) $350^{\circ} \mathrm{C}, 400^{\circ} \mathrm{C}, 450^{\circ} \mathrm{C}$ and $500^{\circ} \mathrm{C}$. The T6 tempering procedure includes the following steps: a). SHT heating temperature with temperature variations (350 - $500{ }^{\circ} \mathrm{C}$ ), b). Quenching, and c). Tempering (with a temperature of $120^{\circ} \mathrm{C}$ for 2 days). Meanwhile, after the case hardening process using the pack carburizing method, the tempering case hardening process is carried out. Vickers hardness test, tensile test, microstructure test, and xrd test were conducted. The highest hardness and tensile strength were obtained after TCH and T6 treatment at SHT 500C, including 182.5 and 171 VHN hardness, 613.3 and 618.3 MPa.

Keywords: Aluminum 7075, Tempering Case Hardening, T6, Vickers Hardness, Tensile Strength. 


\section{PENDAHULUAN}

Aluminium merupakan logam yang paling banyak digunakan setelah baja, karakteristik utamanya adalah ringan (berat jenis $=2.7 \mathrm{~g} / \mathrm{cm} 3$ ), memiliki konduktivitas panas dan listrik yang tinggi, dan ketahanan korosi yang baik dalam atmosfer biasa, serta memiliki keuletan cukup tinggi. Aluminium jauh lebih ringan dibanding baja (berat jenis $=7.8$ $\left.\mathrm{g} / \mathrm{cm}^{3}\right)$. [1]

Aluminium banyak digunakan di industri otomotif dikarenakan ringan dan penggunaannya pada mobil, baik itu komponen pada mobil berbahan bakar bensin, dan berbahan bakar alternatif, yang sedang disoroti saat ini yaitu mobil dengan bahan bakar alternatif, yaitu salah satunya energi listrik, yang mana jika diaplikasikan yaitu menggunakan daya berupa baterai ataupun aki. Keuntungan dari mobil berbahan bakar listrik yaitu: a). Ramah lingkungan, b). Mengurangi penggunaan bahan bakar minyak, c). Minim suara. Sedangkan kekuranganya yaitu: a). Kecepatannya rendah, b). Penggunaan baterai terbatas. Hal ini disebabkan oleh beban dari mobil tersebut yang mengurangi daya penggunaan baterai. Untuk mengatasi hal itu maka peggunaan bahan aluminium untuk mengurangi beban dari mobil. [2] Aluminium yang digunakan yaitu seri 7075 memiliki unsur paduan utama $\mathrm{Zn}$, yang mana disebut juga sebagai duralumin super ekstra (ESD), aluminium tersebut memiliki kekuatan yang paling tinggi diantara paduan aluminium lainnya. [3]

Aluminium 7075 merupakan logam yang dapat dilakukan perlakuan panas (heat-tretable). Proses perlakuan panas (heat treatment) dapat meningkatkan sifat mekanik seperti kekerasan dan kekuatan tarik. Perlakuan panas pada aluminium 7075 yaitu T6 dengan 3 tahapan: a). Pemanasan suhu solution heat treatment (SHT), b). Quenching, c. Tempering. [4]

Selain itu metode case hardening digunakan untuk mendapatkan kekerasan pada permukaan tapi ulet pada bagian intinya, proses case hardening dapat menyebabkan terbentuknya ceramic seperti fasa $\mathrm{Al}_{4} \mathrm{C}_{3}[2,5,6,7,8]$, yang menyebabkan kekerasannya meningkat $[2,5]$.

Proses tempering dilakukan dengan variasi suhu SHT $450-480{ }^{\circ} \mathrm{C}$ dan suhu aging $120-185{ }^{\circ} \mathrm{C}$ [9].

Proses tempering dapat meningkatkan sifat mekanik dikarenakan terbentuknya prestipitat $\mathrm{MgZn}_{2}$ dan $\mathrm{Al}_{2} \mathrm{CuMg}[4,9,10,11]$.
Pada penelitian ini berfokus untuk membandingkan perlakuan T6 dan temper case hardening untuk mengetahui pengaruhnya pada kekerasan dan kekuatan tariknya.

\section{METODE}

Penelitian ini dilakukan di Politeknik ATMI, Pengujian di Lab MIPA UNY, Lab Material UNS, dan CV KHS, Pengujian yang dilakukan yaitu: uji kekerasan, uji tarik, uji struktur mikro dan uji xrd, penjelasannya sebagai berikut:

a. Pembuatan benda uji kekerasan dengan ukuran $25 \times 25 \times 5 \mathrm{~mm}$ dengan mesin frais.
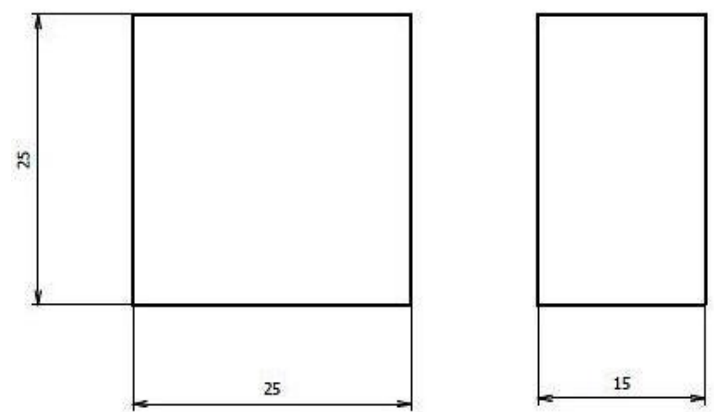

Gambar 1. Ukuran Spesimen uji kekerasan

b. Pembuatan benda uji tarik dengan ukuran standard ASTM B557-84

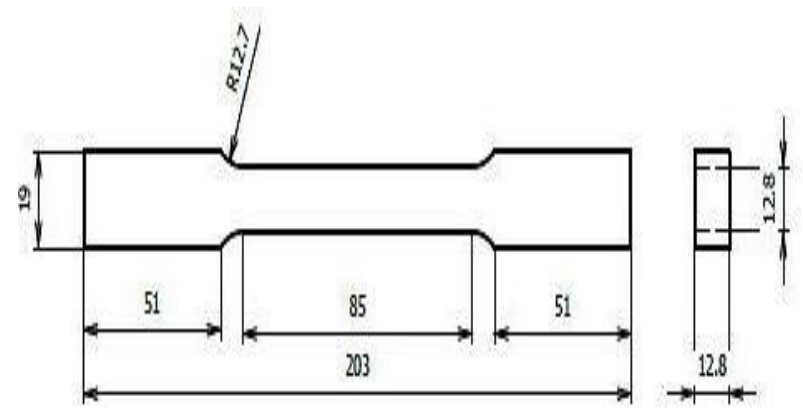

Gambar 2. Ukuran Spesimen uji tarik

c. Proses T6 dengan tahapan pemanasan di oven dengan variasi suhu SHT 350, 400, 450, dan $500^{\circ} \mathrm{C}$. dilanjutkan quenching pada larutan nitratnitrit dengan komposisi $\mathrm{NaNO}_{2} 100$ gr, $\mathrm{NaNO}_{3}$ $100 \mathrm{gr}$, dan air $250 \mathrm{~mL}$. Setelah itu proses aging selama 2 hari dengan suhu $120^{\circ} \mathrm{C}$. 


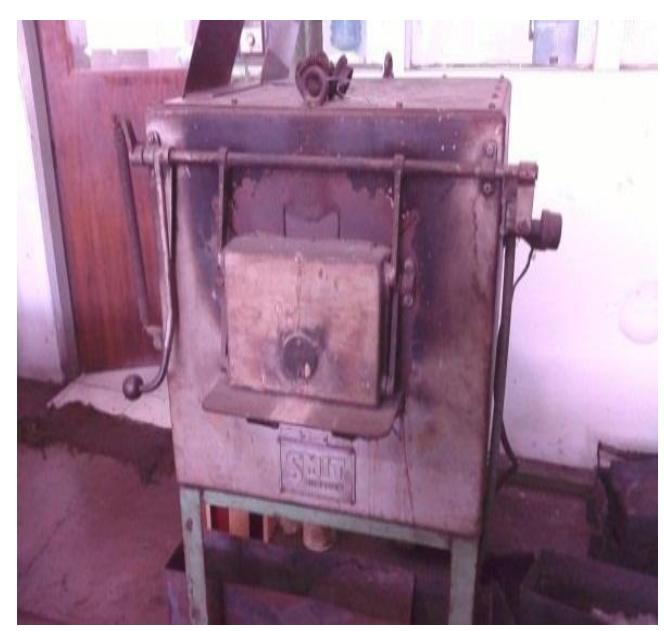

Gambar 3. Pemanasan Suhu SHT

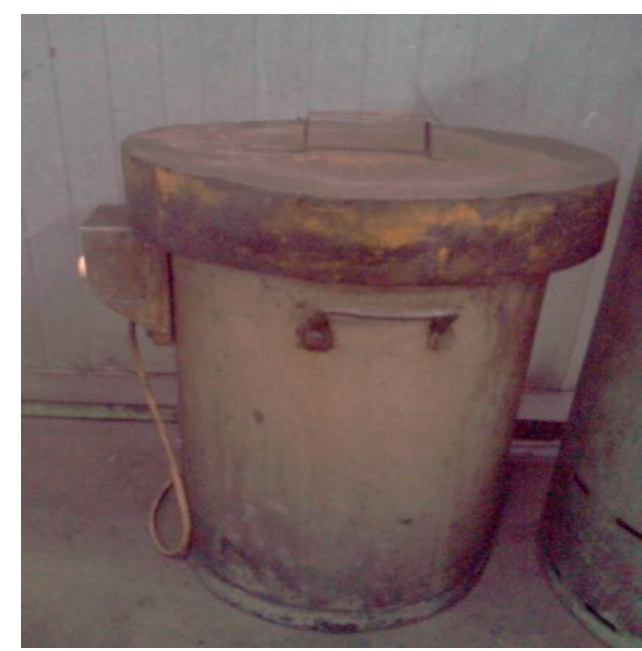

Gambar 4. Pemanasan Aging

d. Proses temper case hardening dengan tahapan case hardening terlebih dahulu yaitu: pemanasan di oven dengan variasi suhu SHT 350, 400, 450, dan $500^{\circ} \mathrm{C}$ dengan posisi spesimen berada pada wadah kotak stainless steel berukuran $25 \times 7.5 \times 4$ $\mathrm{cm}$ dan di benamkan dalam serbuk arang dengan komposisi Arang : $\mathrm{BaCO}_{3}: \mathrm{NaCO}_{3}: \mathrm{CaCO}_{3}$ sebesar $6: 3: 2: 1$, dilanjutkan quenching pada larutan nitrat-nitrit dengan komposisi $\mathrm{NaNO}_{2} 100$ gr, $\mathrm{NaNO}_{3} 100$ gr, dan air $250 \mathrm{ml}$. Setelah itu proses aging selama 2 hari dengan suhu $120^{\circ} \mathrm{C}$.

e. Pengujian kekerasan dilakukan pada spesimen ukuran $25 \times 25 \times 5 \mathrm{~mm}$ menggunakan micro vickers HWMMT-X7, load 100 gf, dwell time 10 detik, dengan jarak uji dari tepi luar ke inti 0.25, 0.75, 1.25 , dan $1.75 \mathrm{~mm}$.

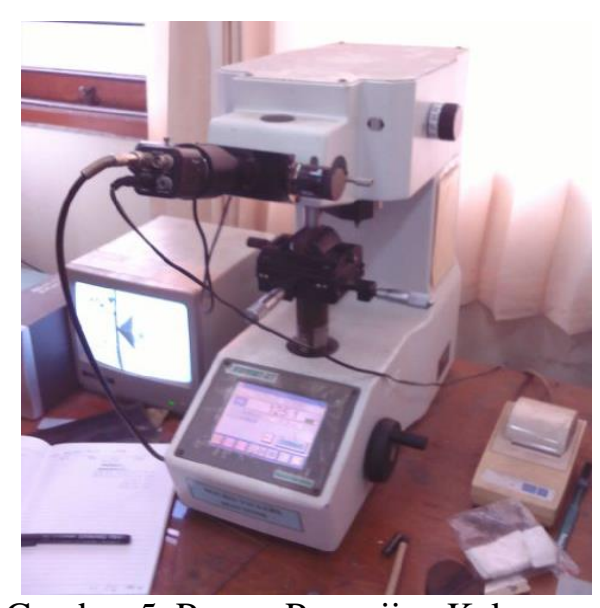

Gambar 5. Proses Pengujian Kekerasan

f. Pengujian tarik dilakukan pada spesimen dengan ukuran mengacu pada ASTM B557-84 dengan SANS UTM dan tensile rate $2 \mathrm{~mm} /$ menit.

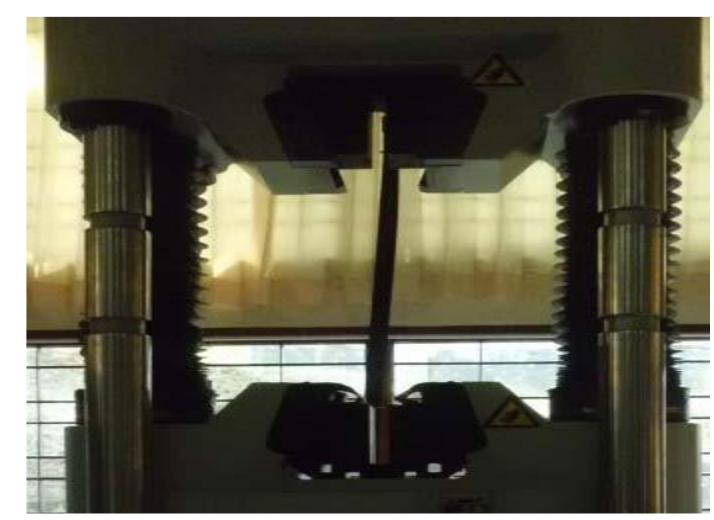

Gambar 6. Proses Pengujian Tarik

g. Pengujian strukur mikro menggunakan mikroskop optik dengan pembesaran 10X dengan komposisi cairan etsa $30 \mathrm{~mL} \mathrm{HCL}, 40$ $\mathrm{mL} \mathrm{HNO}_{3}, 2.5 \mathrm{~mL} \mathrm{HF}, 12 \mathrm{~g} \mathrm{CrO}_{3}$, dan $42.5 \mathrm{~mL}$ Air.

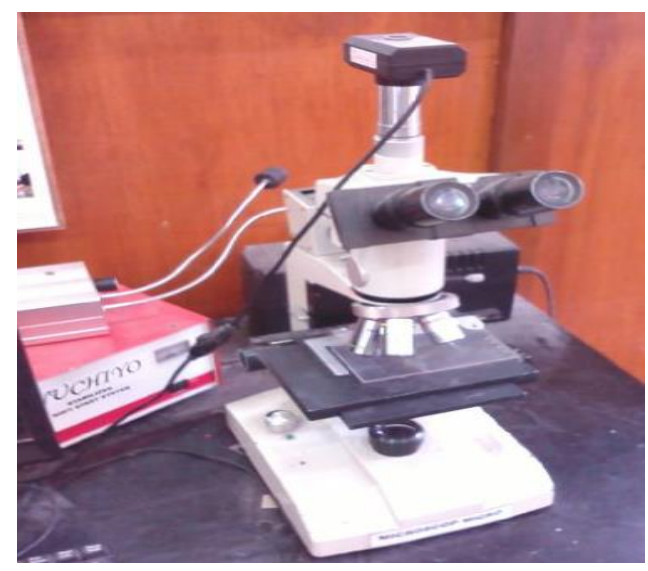

Gambar 7. Alat uji struktur mikro 
h. Pengujian XRD menggunakan mesin Rigaku dengan sudut 2 theta $4-80^{\circ}$ pada material aluminium 7075 tanpa perlakuan / raw material (RM), Aluminium 7075 T6 dan Aluminium 7075 $\mathrm{TCH}$.

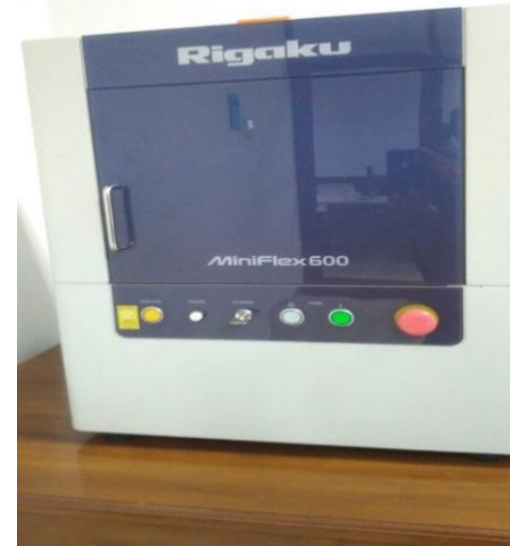

Gambar 8. Alat uji XRD Rigaku

i. Pengujian komposisi kimia aluminium 7075 dilakukan di CV. KHS (QUICK) Yogyakarta.

\section{HASIL DAN PEMBAHASAN}

Hasil uji komposisi kimia aluminium 7075 dapat dilihat pada tabel 1. Dari hasil tersebut bahwa material tersebt sesuai dengan Standard ASTM yang mana kandungan $\mathrm{Zn}$ pada aluminium 7075 (5.1-6.1\%).

Tabel 1. Komposisi kimia aluminium 7075

\begin{tabular}{c|c}
\hline Elemen & $(\boldsymbol{\%})$ \\
\hline $\mathrm{Si}$ & 0.01 \\
$\mathrm{Fe}$ & 0.1089 \\
$\mathrm{Cu}$ & 1.133 \\
$\mathrm{Mn}$ & 0.0162 \\
$\mathrm{Mg}$ & 1.8635 \\
$\mathrm{Zn}$ & 5.8113 \\
$\mathrm{Ti}$ & 0.0916 \\
$\mathrm{Cr}$ & 0.0916 \\
$\mathrm{~Pb}$ & 0.0015 \\
$\mathrm{Sn}$ & 0.004 \\
$\mathrm{Al}$ & 90.75 \\
\hline
\end{tabular}

Hasil uji kekerasan pada perlakuan T6 dapat dilihat pada Gambar 9. Angka kekerasan terbesar pada variasi suhu SHT $500^{\circ} \mathrm{C}$, dengan hasil dari jarak $0.25-1.75 \mathrm{~mm}$ yaitu $171,178.6,181.8$, dan 175.2 VHN, kekerasan dari jarak tersebut menunjukkan kekerasan yang merata dari tepi luar hingga inti.
Hasil uji kekerasan pada perlakuan temper case hardening (TCH) ditunjukkan pada Gambar 10. Angka kekerasan terbesar pada variasi suhu SHT $500^{\circ} \mathrm{C}$, dengan hasil dari jarak $0.25-1.75 \mathrm{~mm}$ yaitu 182.5, 189.5, 177.3 , dan 184.4 VHN, kekerasan dari jarak tersebut menunjukkan kekerasan yang merata dari tepi luar hingga inti, yang membedakan dari perlakuan T6 yaitu jika dilihat dari jarak pengujian $0.25 \mathrm{~mm}$ pada perlakuan TCH dan T6 yaitu 182.5 dan 171 VHN serta jika dilihat dari variasi suhu SHT $350-500^{\circ} \mathrm{C}$ maka pada perlakuan $\mathrm{TCH}$ lebih stabil dan merata kekerasannya dari tepi luar ke inti dibandingkan dengan perlakuan T6

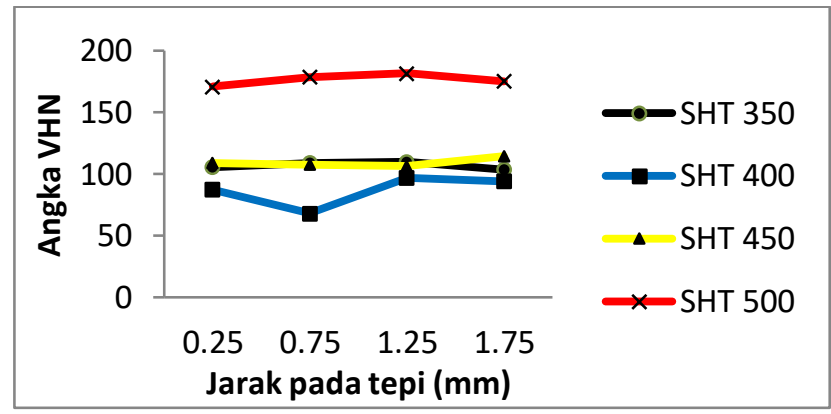

Gambar 9. Grafik Kekerasan T6

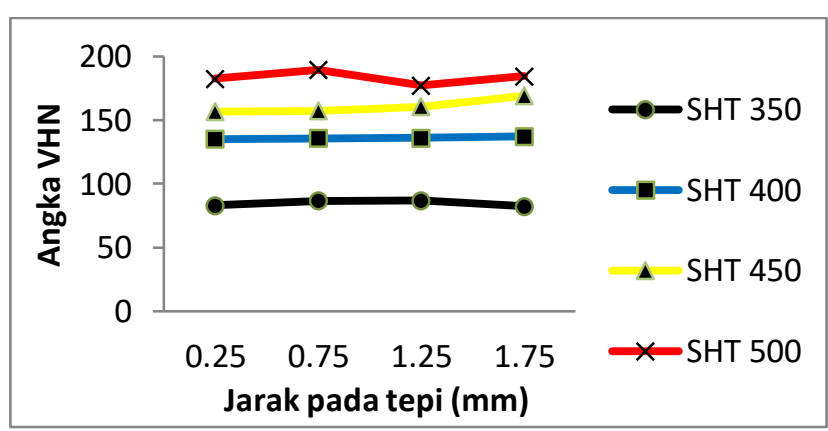

Gambar 10. Grafik Kekerasan TCH

Perbandingan hasil uji kekerasan pada RM, T6 dan TCH dapat dilihat pada Gambar 11. yaitu 59.1, 171, dan 182.5 VHN. Perlakuan TCH memiliki kekerasan paling besar.

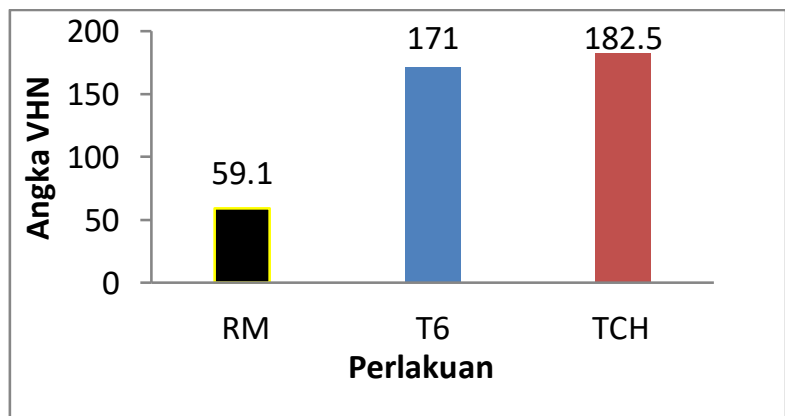

Gambar 11. Grafik Kekerasan RM, T6, dan TCH 
Hasil uji tarik pada perlakuan T6 dengan variasi SHT $350-500^{\circ} \mathrm{C}$ dapat dilihat pada Gambar 12. Terjadi kenaikan kekuatan tarik antar suhu SHT yaitu: 318.3 , 415, 571.7, 618.3 MPa. Kekuatan tarik terbesar pada suhu SHT $500^{\circ} \mathrm{C}$.

Hasil uji tarik pada perlakuan TCH dengan variasi SHT $350-500^{\circ} \mathrm{C}$ dapat dilihat pada Gambar 13. Terjadi kenaikan kekuatan tarik antar suhu SHT yaitu: 366.7, 483.3, 598.3, 613.3 MPa. Kekuatan tarik terbesar pada suhu SHT $500^{\circ} \mathrm{C}$.

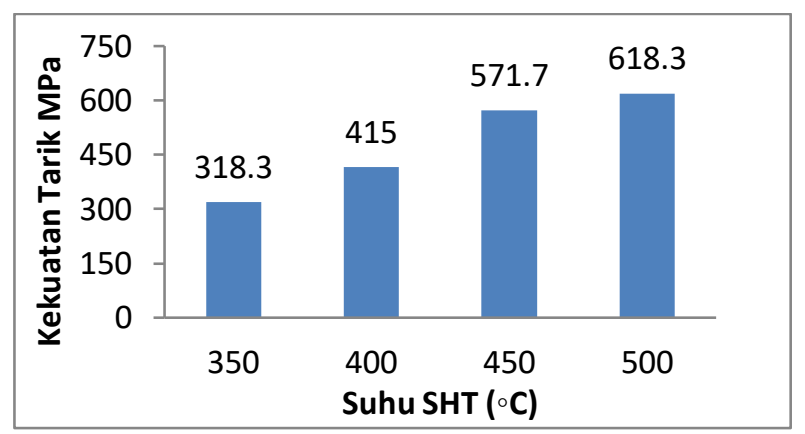

Gambar 12. Kekuatan Tarik T6 dengan variasi suhu SHT $350-500{ }^{\circ} \mathrm{C}$

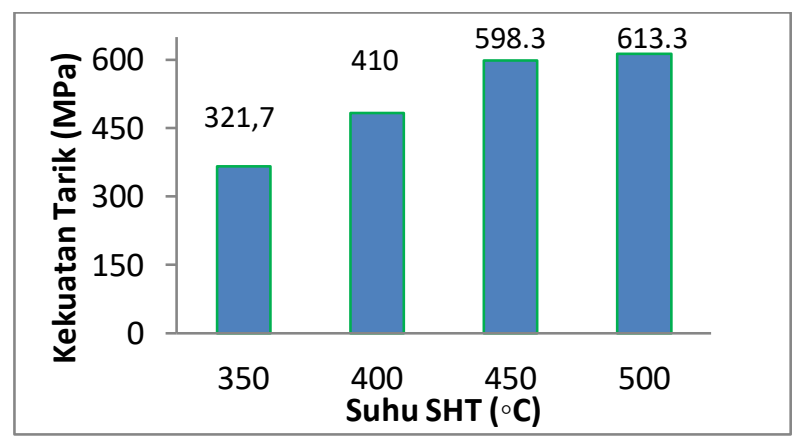

Gambar 13. Kekuatan Tarik TCH dengan variasi suhu SHT $350-500{ }^{\circ} \mathrm{C}$

Perbandingan Hasil uji tarik pada perlakuan RM, T6, TCH suhu SHT $500^{\circ} \mathrm{C}$ dapat dilihat pada Gambar 14. Yaitu 235.7, 618.3, 613.3 MPa.

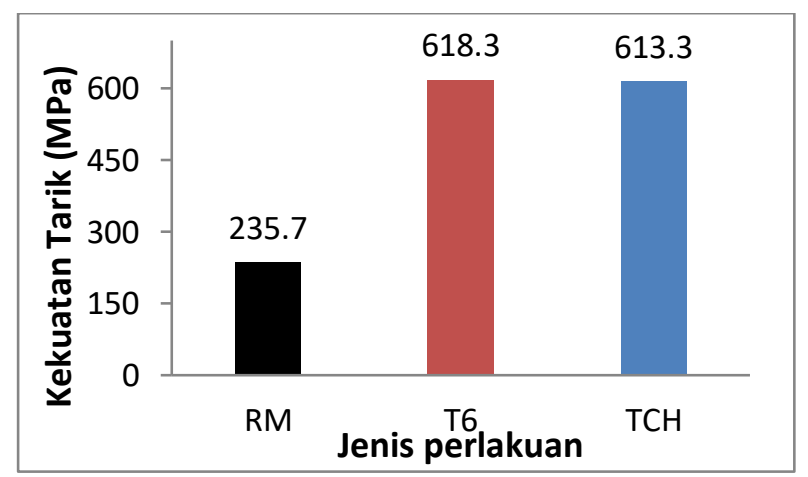

Gambar 14. Perbandingan Kekuatan Tarik RM, T6, dan $\mathrm{TCH}$
Hasil xrd pada Gambar 15. Menunjukkan pada perlakuan TCH dan T6 terbentuknya matriks prestipitat $\mathrm{Al}_{2} \mathrm{CuMg}$ pada 2 theta (41.22 dan 68.33), $\mathrm{MgZn}_{2}$ pada 2 theta (21.6 dan 42.69), hal ini sesuai dengan penelitian Li, J.F, et al. [9], Padap, A.K., et al. [11] dan Darsono, F.B, et al. [4]. Terbentuknya matriks tersebut karena proses temper yang menyebabkan peningkatan kekuatan tarik. Pada perlakuan $\mathrm{TCH}$ terbentuk fasa $\mathrm{AL}_{4} \mathrm{C}_{3}$ dengan 2 theta (34.31, 43.27, dan 64.85) hal ini sesuai dengan penelitian Murtaza, N, et al. [5], Wu, J, et al. [6], dan Darsono, F.B, et al. [2]. Fasa $\mathrm{Al}_{4} \mathrm{C}_{3}$ menyebabkan kenaikan kekerasan pada tepi permukaan, dikarenakan adanya matriks prestipitat maka menyebabkan kekerasannya merata dapat dilihat pada Gambar 10, jika dibandingkan dengan perlakuan T6 kekerasannya meningkat karena prestipitat, tetapi tidak begitu stabil jika dibandingkan $\mathrm{TCH}$ jika dilihat pada Gambar 9.

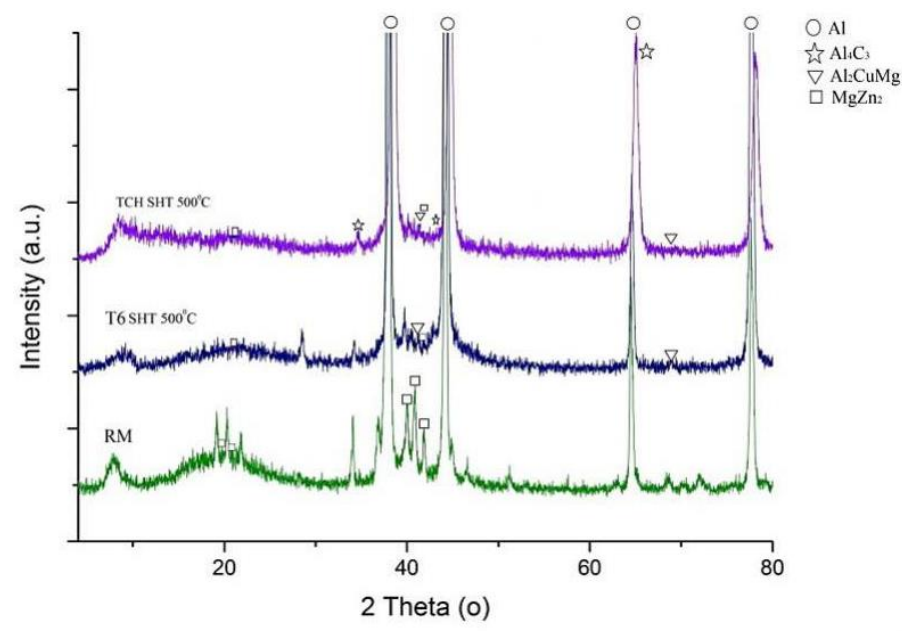

Gambar 15. Perbandingan XRD RM, T6, TCH SHT $500^{\circ} \mathrm{C}$

Perbandingan Hasil foto struktur mikro RM dengan perlakuan T6 dan TCH suhu SHT $500^{\circ} \mathrm{C}$ dapat dilihat pada Gambar 16, 17, dan 18. Maka batas butirnya semakin terbentuk saat perlakuan tersebut.

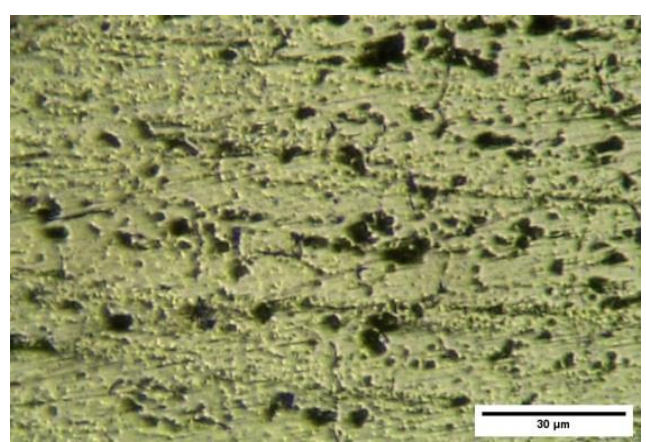

Gambar 16. Struktur Mikro RM 


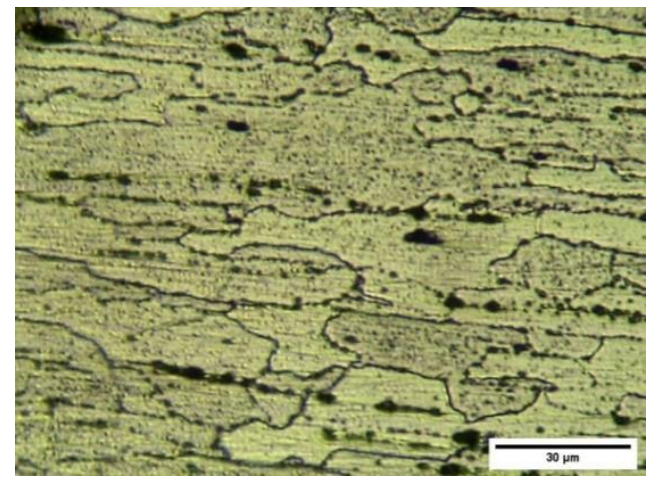

Gambar 17. Struktur Mikro T6 Jarak 0,25 mm

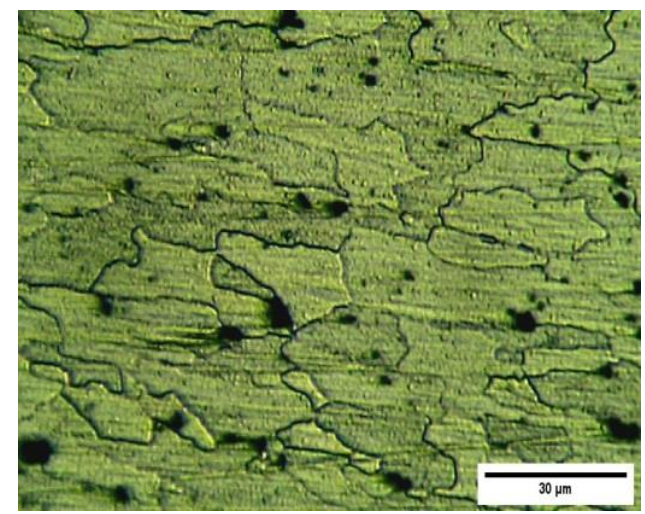

Gambar 18. Struktur Mikro TCH Jarak 0,25 mm

\section{KESIMPULAN}

Berdasarkan dari hasil penelitian menunjukkan kekerasan dan kekuatan tarik terbesar pada perlakuan temper case hardening (TCH) dan perlakuan T6 pada suhu SHT $500{ }^{\circ} \mathrm{C}$ yaitu sebesar 182.5 dan 171 VHN serta 613.3 dan 618.3 Mpa Penyebab kekerasan meningkat pada perlakuan temper case hardening $(\mathrm{TCH})$ karena terbentuknya fasa $\mathrm{Al}_{4} \mathrm{C}_{3}$, serta kekerasannya merata dari tepi luar hingga ke inti karena terbentuknya prestipitat $\mathrm{Al}_{2} \mathrm{CuMg}$ dan $\mathrm{MgZn}_{2}$, sedangkan pada perlakuan $\mathrm{T} 6$ kekerasannya meningkat dan merata dari tepi luar ke inti, tetapi tidak sestabil pada perlakuan $\mathrm{TCH}$, dikarenakan hanya terbentuk prestipitat $\mathrm{Al}_{2} \mathrm{CuMg}$ dan $\mathrm{MgZn}_{2}$. Terbentuknya prestipitat pada kedua perlakuan tersebut menyebabkan kenaikan kekuatan tarik.

\section{DAFTAR PUSTAKA}

[1] Sofyan, B. T. (2011). Pengantar Material Teknik. Jakarta: Salemba Teknika.
[2] Darsono, F. B., Triyono, T., \& Surojo, E. (2018, February). The effect of case hardening treatment on aluminum 7075 toward its hardness and tensile strength. In AIP Conference Proceedings (Vol. 1931, No. 1, p. 030058). AIP Publishing LLC.

[3] Surdia, T. (2013). Pengetahuan Bahan Teknik. Jakarta: Balai Pustaka.

[4] Darsono, F. B., \& Koin, S. T. (2021, March). The Effect of T6 Heat Treatment on 7075 Aluminum on its Hardness and Tensile Strength. In IOP Conference Series: Materials Science and Engineering (Vol. 1096, No. 1, p. 012042). IOP Publishing.

[5] Murtaza, G., Hussain, S. S., Sadiq, M., \& Zakaullah, M. (2009). Plasma focus assisted carburizing of aluminium. Thin Solid Films, 517(24), 6777-6783.

[6] Wu, J., Liu, R., Wang, B., Yang, C., Qu, Y., \& Xue, W. (2015). Preparation and characterization of carburized layer on pure aluminum by plasma electrolysis. Surface and Coatings Technology, 269, 119-124.

[7] Fariaut, F., Boulmer-Leborgne, C., Le Menn, E., Sauvage, T., Andreazza, C., Andreazza, P., \& Langlade, C. (2001). Surface carburization of aluminum alloys by excimer laser. Surface and Coatings Technology, 146, 324-330.

[8] Fariaut, F., Boulmer-Leborgne, C., Le Menn, E., Sauvage, T., Andreazza-Vignolle, C., Andreazza, P., \& Langlade, C. (2002). Excimer laser induced plasma for aluminum alloys surface carburizing. Applied surface science, 186(1-4), 105-110. 
[9] Li, J. F., Peng, Z. W., Li, C. X., Jia, Z. Q., Chen, W. J., \& Zheng, Z. Q. (2008). Mechanical properties, corrosion behaviors and microstructures of 7075 aluminium alloy with various aging treatments. Transactions of Nonferrous Metals Society of China, 18(4), 755-762.

[10] Mahathaninwong, N., Plookphol, T., Wannasin, J., \& Wisutmethangoon, S. (2012). T6 heat treatment of rheocasting $7075 \mathrm{Al}$ alloy. Materials Science and Engineering: A, 532, 91-99.

[11] Padap, A. K., Yadav, A. P., Kumar, P., \& Kumar, N. (2020). Effect of aging heat treatment and uniaxial compression on thermal behavior of 7075 aluminum alloy. Materials Today Proceedings, 33, 544 